\title{
The occurrence of gonadal dysgenesis in association with monozygotic twinning*
}

\author{
LAURENCE KARP, J. I. BRYANT, GEORGE TAGATZ, ELOISE GIBLETT, \\ and PHILIP J. FIALKOW \\ From the Departments of Obstetrics and Gynecology, Medicine and Genetics, University of Washington, \\ and the King County Central Blood Bank, Seattle, Washington, USA
}

\begin{abstract}
Summary. A case is presented of a monozygotic twin pair, discordant for phenotypic sex, in which the female member showed gonadal dysgenesis and chromosomal mosaicism. Review of the pertinent literature reveals that in monozygotic twin pairs, phenotypic and karyotypic concordance is the usual occurrence for Down's and Klinefelter's syndromes, whereas discordance often accompanies gonadal dysgenesis. Mosaicism is a frequent concomitant of gonadal dysgenesis in monozygotic twins. Our case strengthens the probability of a real association between mosaicism and monozygotic twinning in gonadal dysgenesis.
\end{abstract}

We wish to report another example of gonadal dysgenesis occurring in only one of a pair of monozygotic twins.

\section{Case report}

History. The proposita, a Caucasian female, was referred to the University of Washington Hospital in September, 1968 at age 17 for evaluation of primary amenorrhoea, lack of breast development, and short stature.

The patient was one of a set of twins born at full term after an uncomplicated pregnancy. Her birth weight was $2412 \mathrm{~g}$ and that of her brother was $3001 \mathrm{~g}$. At the time, the obstetrician noted there was 'only one placenta'. For the first year of the twins' lives, except for the weight difference, the mother could not tell them apart with their diapers on. Their prepubertal development was within normal limits; they were both very good students, and they were healthy throughout childhood.

The male twin underwent normal pubertal development at age 14, with normal male sexual maturation and growth to $168 \mathrm{~cm}$ by age 17 . The patient, on the other hand, had some growth of pubic and axillary hair at approximately age 14, but she had no growth spurt, breast development, or menses. By age 17, she was notably shorter than her classmates.

Physical examination. Height $144 \mathrm{~cm}$, weight $51 \cdot 3 \mathrm{~kg}$, blood pressure $120 / 80$. The posterior hairline

Received 7 February 1974.

* These studies were supported in part by US Public Health Service Grant GM 15253. extended down the midline to the thoracic vertebrae with some further midline hair growth. The palate was arched. The neck was not webbed, and the thyroid gland not enlarged. The right pupil was 1-2 mm larger than the left; both irises were evenly coloured. No cardiovascular abnormalities were noted. The breasts were small, and the nipples and areolas undeveloped. Between the breasts there was a $2 \times 3 \mathrm{~cm}$ area of coarse black hair. Black hair grew abundantly on the arms, pubis, abdomen, and the moustache area. There was a moderately-increased carrying angle at the right elbow. The clitoris was enlarged, measuring $3 \times 0.7 \mathrm{~cm}$. The vaginal mucosa appeared hypoestrogenic, being thin and red, with little rugosity. The cervix was small, and the uterus was approximately $4 \times 2 \mathrm{~cm}$; the gonads were not palpable. Neurological examination was grossly normal. Colour vision, evaluated by the pseudoisochromatic plates of Hardy-Rand-Rittler (1957 edition), revealed moderately severe deuteranopia in both twins. The mother and all other sibs had normal colour vision. (Fig. 1).

Family history (Fig. 2). The twins have a younger brother with first-degree hypospadias; two other sibs and two half-sibs are normal in all respects. The twins' father died in a drowning accident; he reportedly had red-green colour blindness.

\section{Laboratory examinations}

The patient's haematocrit was $40 \%$. Twentyfour-hour urinary FSH excretion (ovarian augmentation assay) was $133 \mathrm{IU}$ (normal range 1.8-2.5 IU 


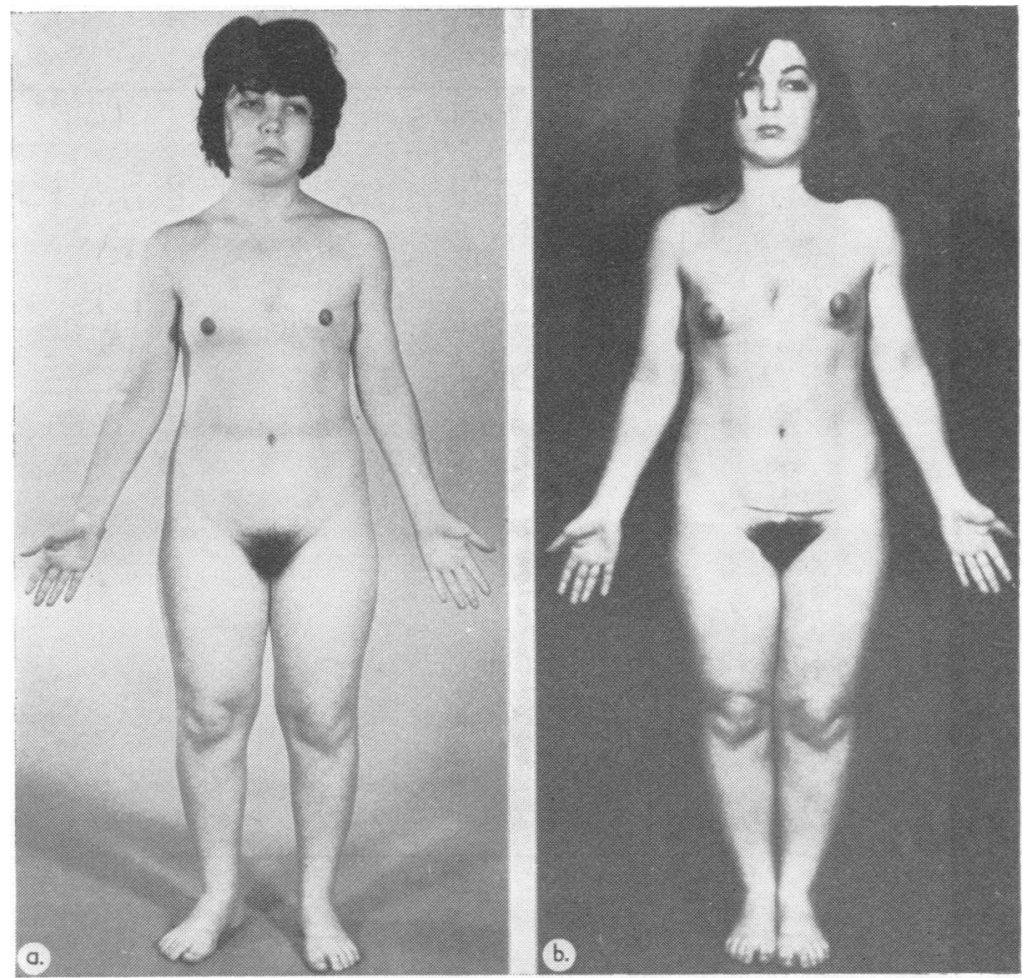

FIG. 1. The patient before (a) and after (b) oestrogen therapy.

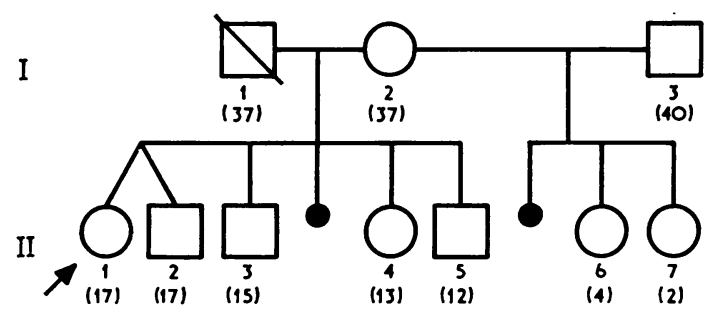

FIG. 2. Family pedigree.

second International Reference Preparation/24 hours); the 24-hour urinary 17-ketosteroid excretion, measured on three occasions, was $5.3 \mathrm{mg}$, $12.3 \mathrm{mg}$, and $12.4 \mathrm{mg}$. Twenty-four-hour urinary oestriol excretion was $3.5 \mu \mathrm{g}$ on one occasion and $4.0 \mu \mathrm{g}$ on another occasion (normal range for nonpregnant, reproductive-age women is 4 to $20 \mu \mathrm{g}$ ). Thyroid function studies were normal, as were the levels of blood urea nitrogen, electrolytes, creatinine, alkaline phosphatase, bilirubin, glucose, calcium, phosphorus, and total protein. Radiology revealed a retarded bone age, corresponding to $13 \frac{1}{2}$ to
14 years, as well as the following findings consistent with gonadal dysgenesis: generalized hypomineralization; short metacarpals (especially the right fourth); altered relationship of the distal radii and ulnas; relative hypoplasia of the medial tibial condyles with beaking of the medial metaphyses; and slightly increased carrying angle of the elbows. On IVP the right kidney was normal and $12.5 \mathrm{~cm}$ long; the left kidney was rotated and enlarged to $16 \mathrm{~cm}$ with lateral displacement of the ureter. No abnormalities were detected on ECG or chest radiology.

Thyroid antibodies. No anti-thyroglobulin nor anti-thyroid microsomal (tanned red cell and indirect immunofluorescent tests, respectively) antibodies were found in the blood of either twin. However, anti-thyroid microsomal antibodies were detected at a titre of $1: 30$ in the mother's serum. The 15-year-old brother had this antibody at a titre of $1: 30$ and an anti-thyroglobulin antibody titre of $1: 2187$.

Genetic markers (Table I). When the patient's blood was tested for the markers listed in Table I, 
TABLE I

BLOOD AND SERUM GROUP STUDIES

\begin{tabular}{|c|c|c|c|c|c|c|}
\hline Locus & Mother & Female Twin & Male Twin & Brother & Sister & Brother \\
\hline \begin{tabular}{l|} 
Blood-group antiger \\
ABO \\
Rh \\
MNSs \\
P \\
Lutheran \\
Kell \\
Lewis \\
Duffy \\
Kidd \\
Diego \\
Xg
\end{tabular} & 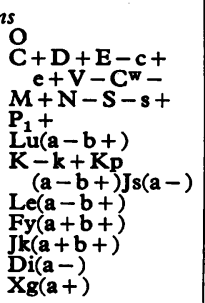 & $\begin{array}{l}\mathbf{O} \\
\mathbf{C}+\mathbf{D}+\mathbf{E}-\mathbf{c}- \\
\mathbf{e}+\mathbf{V}-\mathbf{C}- \\
\mathbf{M}+\mathbf{N}-\mathbf{S}-\mathbf{s}+ \\
\mathbf{P}_{\mathbf{1}}+ \\
\mathbf{L} \mathbf{u}(\mathbf{a}-\mathbf{b}+) \\
\mathbf{K}-\mathbf{k}+\mathbf{K p} \\
\quad(\mathbf{a}-\mathbf{b}+) \mathbf{J s}(\mathbf{a}-) \\
\mathbf{L e}(\mathbf{a}-\mathbf{b}+) \\
\text { Fy(a-b+) } \\
\text { Jk(a+b-) } \\
\text { Di }(\mathbf{a}-) \\
\mathbf{X g}(\mathbf{a}+)\end{array}$ & $\begin{array}{l}\mathbf{O} \\
\mathbf{C}+\mathbf{D}+\mathbf{E}-\mathbf{c}- \\
\mathbf{e}+\mathbf{V}-\mathbf{C}- \\
\mathbf{M}+\mathbf{N}-\mathbf{S}-\mathbf{s}+ \\
\mathbf{P}_{\mathbf{1}}+ \\
\mathbf{L} \mathbf{u}(\mathbf{a}-\mathbf{b}+) \\
\mathbf{K}-\mathbf{k}+\mathbf{K} \mathbf{p} \\
\quad(\mathbf{a}-\mathbf{b}+) \mathbf{J s}(\mathbf{a}-) \\
\mathbf{L e}(\mathbf{a}-\mathbf{b}+) \\
\mathbf{F y}(\mathbf{a}-\mathbf{b}+) \\
\operatorname{Jk}(\mathbf{a}+\mathbf{b}-) \\
\operatorname{Di}(\mathbf{a}-) \\
\mathbf{X g}(\mathbf{a}+)\end{array}$ & 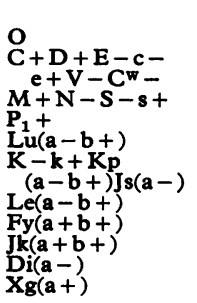 & 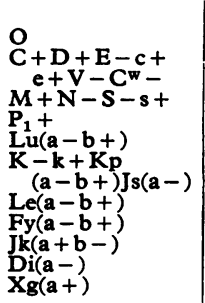 & $\begin{array}{l}\text { O } \\
\mathbf{C}+\mathbf{D}+\mathbf{E}-\mathbf{C}-\mathbf{C}^{\mathbf{w}}- \\
\mathbf{M}+\mathbf{N}-\mathbf{S}-\mathbf{s}+ \\
\mathbf{P}_{\mathbf{1}}+ \\
\mathbf{L} \mathbf{u}(\mathbf{a}-\mathbf{b}+) \\
\mathbf{K}-\mathbf{k}+\mathbf{K} \mathbf{p} \\
\quad(\mathbf{a}-\mathbf{b}+) \mathrm{Js}(\mathbf{a}-) \\
\mathbf{L e}(\mathbf{a}-\mathbf{b}+) \\
\mathbf{F y}(\mathbf{a}-\mathbf{b}+) \\
\mathbf{J k}(\mathbf{a}+\mathbf{b}-) \\
\mathbf{D i}(\mathbf{a}-) \\
\mathbf{X g}(\mathbf{a}+)\end{array}$ \\
\hline $\begin{array}{l}\text { Serum proteins } \\
\text { Hp } \\
\text { Tf } \\
\text { Gc }\end{array}$ & $\begin{array}{l}2-1 \\
C \\
1-1\end{array}$ & $\begin{array}{l}2-1 \\
\mathrm{C}-1\end{array}$ & $\begin{array}{l}2-1 \\
C \\
1-1\end{array}$ & $\begin{array}{l}2-1 \\
C-1\end{array}$ & $\begin{array}{l}2-1 \\
C \\
1-1\end{array}$ & $\begin{array}{l}2-1 \\
1-1\end{array}$ \\
\hline
\end{tabular}

there was no evidence of two separate cell populations. Tests on the blood of the other family members showed that the phenotypes of the patient and her twin brother could have been discordant in at least seven systems ( $R h, M N S s$, Duffy, Kidd, $\mathrm{PGM}_{1}, \mathrm{Hp}$, and colour vision); however, in all of these, they were concordant. This fact alone indicates that the probability of monozygosity is greater than 0.99 .

Cytogenetics (Fig. 3). Bilateral buccal smears from the patient showed no X-chromatin bodies, but Y-chromatin bodies were observed in her buccal smear and lymphocytes. $\mathrm{X}$ - and $\mathrm{Y}$-chromatin patterns of the patient's full sibs and their mother were consistent with phenotypic sex.

All but one of 50 phytohaemagglutinin-stimulated blood lymphocytes examined from the male twin contained 46 chromosomes, and karyotypes were normal 46,XY. The one cell with 45 chromosomes lacked a Y. Forty of 50 blood cells from the patient were intact, with 46 chromosomes and five G-group members; seven cells contained 45 chromosomes and three had less than 45. Only one of

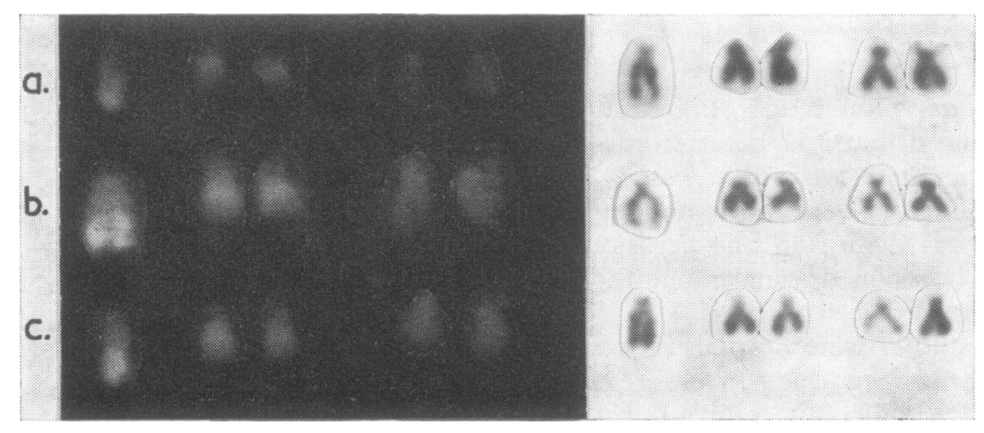

Fig. 3. Composite of G-group chromosomes $(Y, 21,22)$ of the patient (a), her male twin (b), and her younger brother (c). (QM and tetrachrome stains.) 
TABLE II

DERMATOGLYPHIC FINDINGS

Digital ridge counts

\begin{tabular}{|c|c|c|c|c|c|c|c|c|c|c|c|}
\hline & \multicolumn{5}{|c|}{ Left (radial/ulnar) } & \multicolumn{5}{|c|}{ Right (ulnar/radial) } & \multirow{2}{*}{$\begin{array}{l}\text { Total } \\
\text { Ridge } \\
\text { Count }\end{array}$} \\
\hline & 5 & 4 & 3 & 2 & 1 & 1 & 2 & 3 & 4 & 5 & \\
\hline $\begin{array}{l}\text { Patient } \\
\text { Twin } \\
\text { Brother } \\
\text { Brother } \\
\text { Sister }\end{array}$ & $\begin{array}{l}0 / 8 \\
0 / 5 \\
9 / 13 \\
0 / 4 \\
0 / 17\end{array}$ & $\begin{array}{l}0 / 8 \\
0 / 23 \\
7 / 15 \\
0 / 6 \\
12 ! 24\end{array}$ & $\begin{array}{l}2 / 0 \\
0 / 3 \\
0 / 10 \\
4 / 0 \\
0 / 15\end{array}$ & $\begin{array}{r}20 / 0 \\
3 / 0 \\
6 / 0 \\
4 / 0 \\
14 / 0\end{array}$ & $\begin{array}{l}0 / 16 \\
0 / 19 \\
0 / 17 \\
0 / 15 \\
0 / 20\end{array}$ & $\begin{array}{l}20 / 0 \\
19 / 4 \\
17 / 14 \\
20 / 16 \\
21 / 0\end{array}$ & $\begin{array}{l}0 / 0 \\
0 / 0 \\
0 / 9 \\
0 / 6 \\
0 / 14\end{array}$ & $\begin{array}{r}0 / 1 \\
1 / 0 \\
11 / 0 \\
4 / 0 \\
11 / 0\end{array}$ & $\begin{array}{c}15 / 0 \\
23 / 0 \\
11 / 10 \\
7 / 0 \\
24 / 0\end{array}$ & $\begin{array}{c}15 / 0 \\
4 / 0 \\
16 / 10 \\
7 / 0 \\
18 / 0\end{array}$ & $\begin{array}{r}115 \\
100 \\
125 \\
77 \\
178\end{array}$ \\
\hline
\end{tabular}

Palmar formulae*

\begin{tabular}{|c|c|c|}
\hline & Left & Right \\
\hline $\begin{array}{l}\text { Patient } \\
\text { Twin } \\
\text { Brother } \\
\text { Brother } \\
\text { Sister }\end{array}$ & 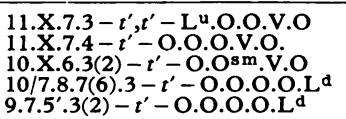 & $\begin{array}{l}\text { 11.0.7.4-t'-O.O.O.O.O } \\
11.7 .7 . t^{\prime}-t^{\prime}-O . O . O . O .1^{d} \\
11.10 .8 .3-t^{\prime}-O . O . O . d^{d} . O \\
11.11(10) .9(8) .4-t^{\prime}-O . O . O . L^{d} . O \\
11(10) .8 .7(6) .3-t^{\prime}-O . O . O . L^{d} . O\end{array}$ \\
\hline
\end{tabular}

* Main line terminations D.C.B.A. - axial triradius position-pattern areas hypothenar -thenar interdigital one $\left(1_{1}\right) \cdot 1_{2} \cdot 1_{3} \cdot 1_{4}$ (Cummins and Midlo, 1961).

these 10 hypomodal cells lacked a G-group member and the rest had random chromosome loss. Karyotypes of intact cells from the patient were indistinguishable from those of her twin. No latelabelled $\mathrm{X}$ was found on radioautographic study, and the presence of the $Y$ chromosome in the patient's blood cells, those of her twin, and those of another brother was confirmed by fluorescence. Lymphocyte karyotypes of the patient's mother and full sibs were consistent with phenotypic sex. All chromosomes appeared morphologically normal. Specifically, the morphology and fluorescence of the patient's $Y$ chromosome did not differ from that observed in her twin and her non-twin brother.

Morphology of ejaculated spermatazoa of the male twin appeared normal. A fluorescent $Y$-chromatin body was noted in $\mathbf{4 5 0}$ of 1000 mature sperm cells.

Dermatoglyphics (Table II). Although dermatoglyphic traits common to all the sibs were observed, the increased similarities of the main line coursings and pattern shapes on both the hands and feet of the patient and her twin were remarkable when contrasted with their sister and brothers.
These similarities were emphasized particularly when main lines and patterns differed as, for example, the right hand main line $C$ which was absent in the patient and which, while present in her twin, recurved almost at the triradial point to form a very small loop distal, ie, while formulated differently both palms expressed the same genetic tendency to suppression at this point. This $\mathrm{C}$-line suppression was complete in both of their left palms and was seen only unilaterally in one brother.

Operative and pathological findings (Fig. $4 a$ and $4 b$ ). Because of the risk of gonadal neoplasm in phenotypic females with a Y chromosome (Fathalla, Rashad, and Kerr, 1966; Taylor, Barter, and Jacobson, 1966; Barr, et al, 1967; Josso et al, 1969), the patient underwent laparotomy, with removal of both fallopian tubes and gonads. The uterus was not removed, so that periodic hormonal withdrawal bleeding could later be induced. Histologically, the right gonad was a streak of fibrous tissue with some ovarian stroma. The left gonad consisted mainly of fibrous stroma, but there was a focus of seminiferous tubules which contained

TABLE III

CHROMOSOME ANALYSIS OF CELLS FROM BLOOD, GONADS, AND TUBES

\begin{tabular}{l|c|c|c|c|c}
\hline & Blood & R. Gonad & L. Gonad & R. Tube & L. Tube \\
\hline $\begin{array}{l}\text { No. of cells counted } \\
\text { No. of cells karyotyped }\end{array}$ & 50 & 103 & 52 & 49 & 100 \\
Cell lines & 11 & 14 & 5 & 19 & 12 \\
\hline
\end{tabular}


FIG. 4a. Right gonad, microscopic section $(\times 100)$.

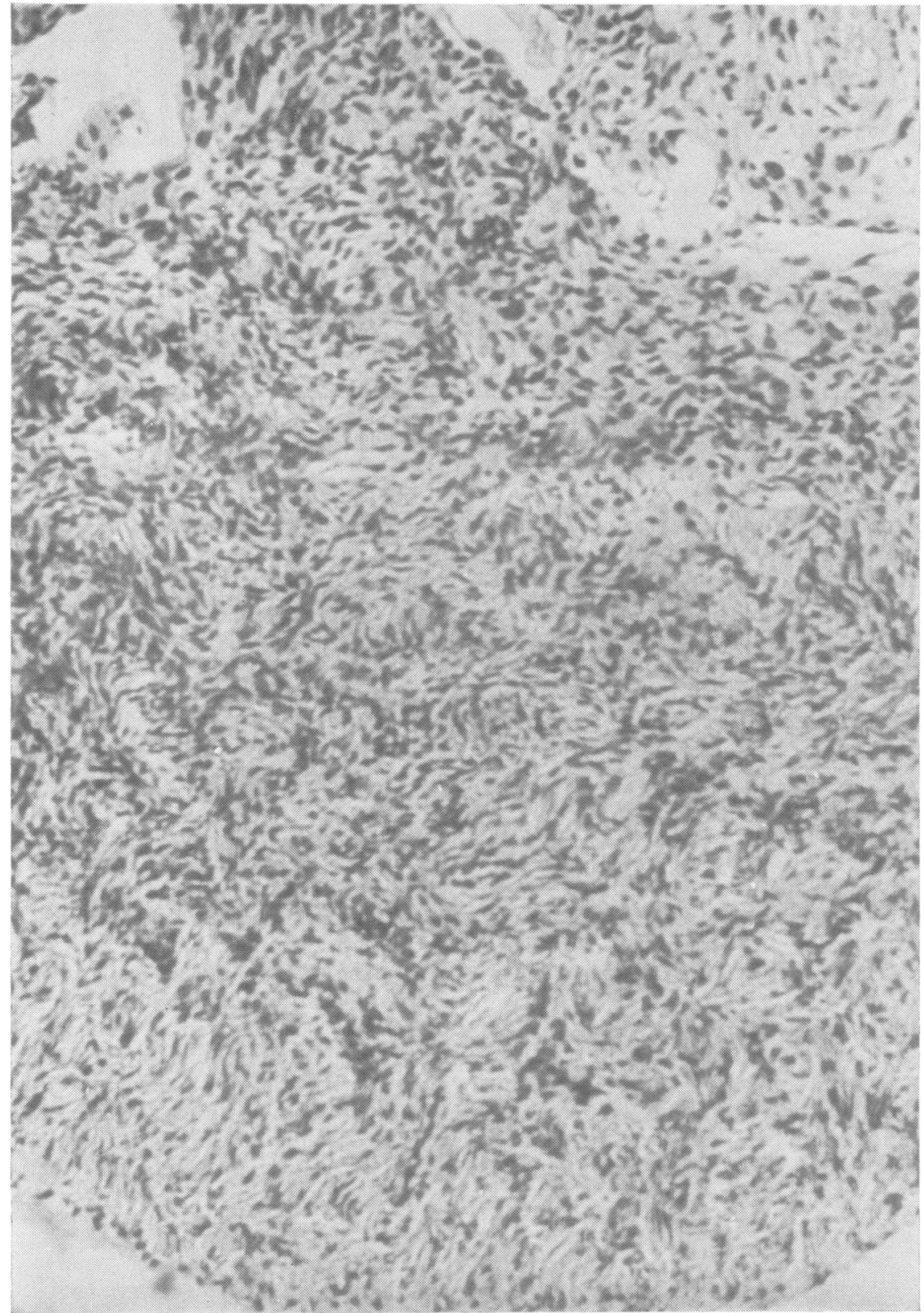




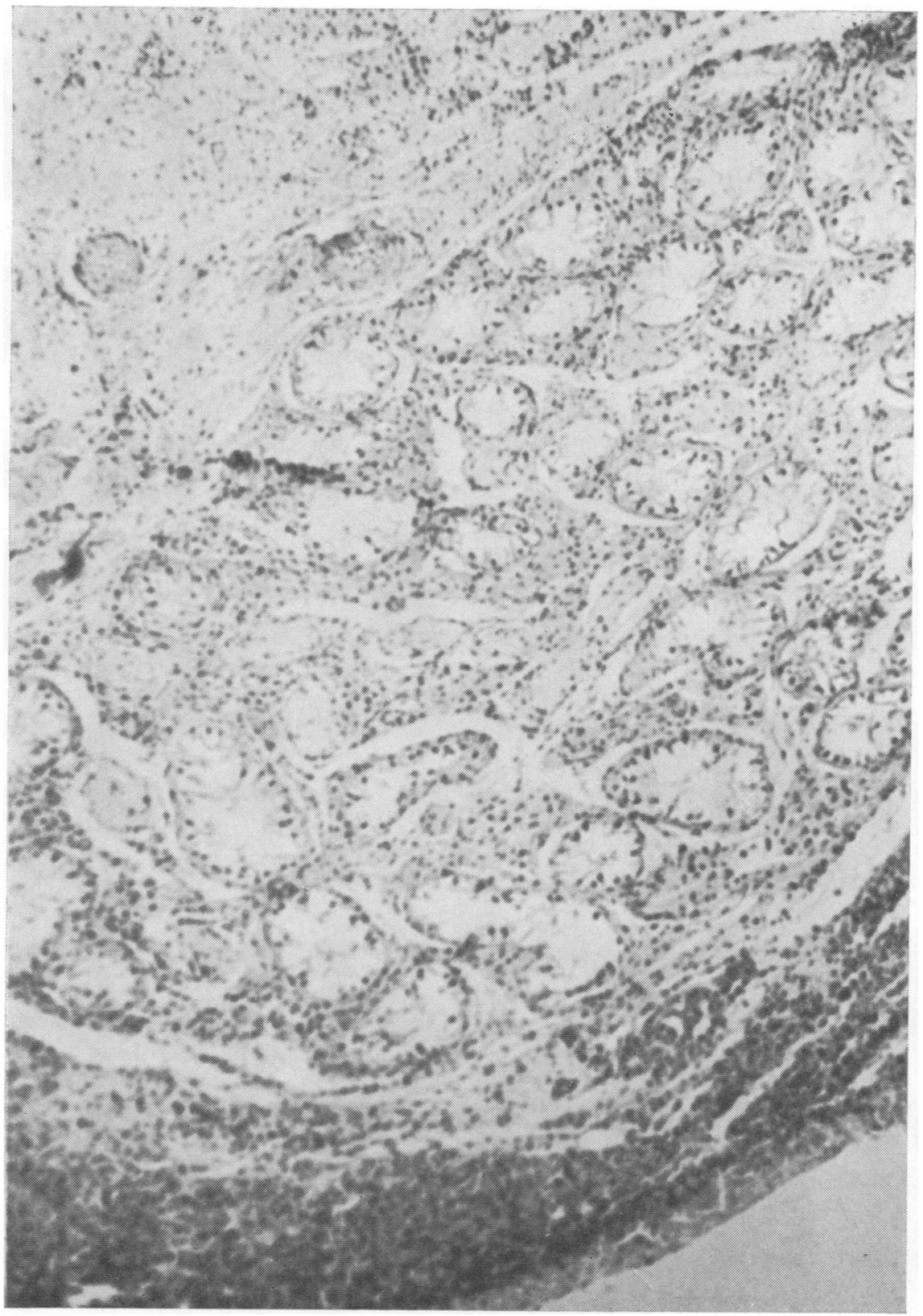

Fig. 4b. Left gonad, microscopic section $(\times 40)$. 

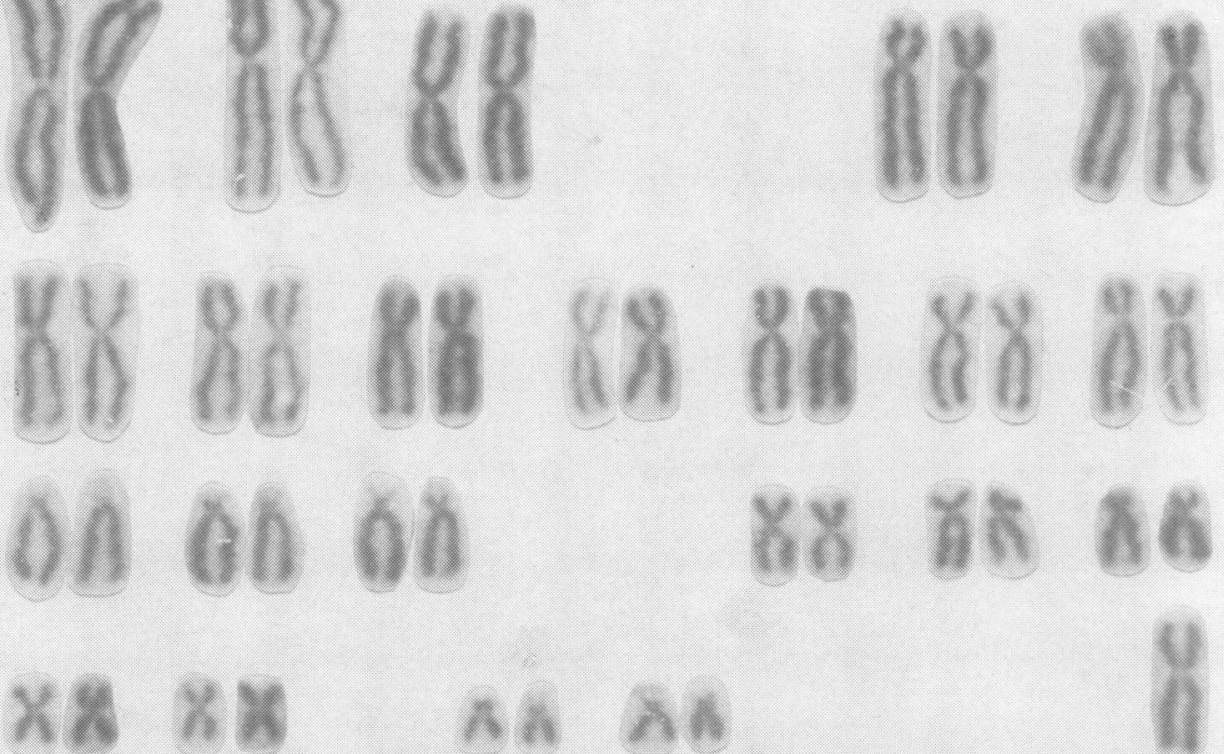

ถูก

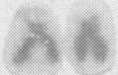

a.

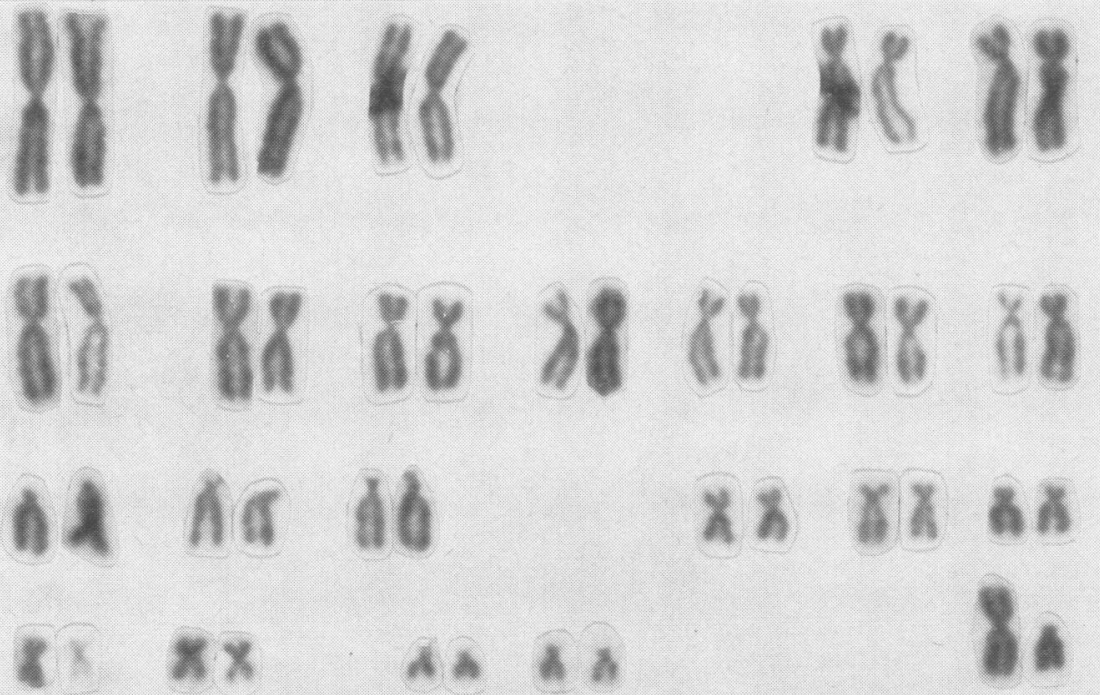

b.

FIG. 5. 45,X karyotype (a) and $46, \mathrm{XY}$ karyotype (b) in the fallopian tube of the patient.

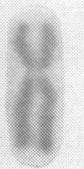


Sertoli cells. In addition, one small area of calcification surrounded by granulosa cells, which possibly might represent gonadoblastoma was noted.

Karyotypes of cultured cells from both gonads were uniformly $45, \mathrm{X}$ but cultures of the fallopian tubes consisted of a mixture of $45, \mathrm{X}$ and $46, \mathrm{XY}$ cells: the percentage ratio of $45, X$ to $46, X Y$ was 66 to 34 on the right and 97 to 3 on the left (Fig. 5 and Table III).

After surgery, cyclic therapy with Enovid E produced withdrawal menstrual bleeding, some degree of breast development, and deposition of fat over the hips and buttocks. Yearly follow-up examinations have shown adequate feminization of all oestrogensensitive tissues and good psychological adjustment to her condition.

\section{Discussion}

Only one of 50 examined blood lymphocytes from the proposita and one of 50 from her co-twin were compatible with a 45,X karyotype. Thus blood mosaicism, a feature of some previous cases of monozygotic twins with discordance for gonadal dysgenesis, was not readily apparent in either member of our twin pair. However, chromosomal mosaicism was evident in cultivated cells from the proposita's rudimentary gonads and fallopian tubes. Since no tissue other than blood was studied in the phenotypically normal male co-twin, we cannot confidently exclude the presence of a minor $45, \mathrm{X}$ cell line.

The causes of chromosomal mosaicism are unknown, but among possible predispositions are parental thyroid autoimmunity or structural chromosome aberrations. For example, in some cases $\mathrm{X} / \mathrm{XY}$ mosaicism has been associated with structural abnormalities of the $\mathrm{Y}$ chromosome (Starkman and Jaffe, 1967; Caspersson et al, 1971; LoCurto et al, 1972). However, fluorescence studies demonstrated identical and apparently normal $Y$ chromosomes in both twins reported here. While it was not possible to examine the father's $Y$, essentially the same information was provided by the $\mathrm{Y}$ chromosome of the non-twin male sib. The proposita's mother and a normal sib had thyroid antibodies and there are data to suggest that the presence of thyroid autoimmunity in a woman predisposes her to a child with a post-zygotic chromosomal abnormality such as XY/X mosaicism (Fialkow, 1966; Fialkow and Uchida, 1968).

The proposita and her twin brother had discordant phenotypes, an observation reported in most previously described monozygotic twin pairs when gonadal dysgenesis is involved (Turpin et al, 1961 ; Mikkelsen, Frøland, and Ellebjerg, 1963; K.
Benirschke and M. M. Sullivan, personal communication; Edwards, Dent, and Kahn, 1966; Shine and Corney, 1966; Jacobs, 1969; Ross, Tjio, and Lipsett, 1969; Potter and Taitz, 1972). In apparent contrast to this are the findings of phenotypic and karyotypic concordance reported in most-but not all (Nielsen, 1967)-monozygotic twin pairs with Down's or Klinefelter's syndrome and in one pair with XYY (Zellweger, 1968; Nicolis et al, 1972; Rainer, Abdullah, and Jarvik, 1972). Since mosaicism occurs in most monozygotic twins with gonadal dysgenesis, both events, twinning and the chromosomal disorder, arose post-zygotically. On the other hand, the abnormalities leading to some, and perhaps to many cases of trisomy 21, XXY and XYY are prezygotic, when concordance in monozygotic twin pairs is more apt to occur.

Mosaicism, detected in our case as well as in several other cases of monozygotic twins discordant for gonadal dysgenesis (Mikkelsen et al, 1963; Edwards et al, 1966; Ross et al, 1969) was also present in at least five (Turner and Zanartu, 1962; Russell et al, 1966; Ferrier, Ferrier, and Kelley, 1970; Muller et al, 1970; van der Horst, Frankel, and Grace, 1971) and probably six (Lemli and Smith, 1963) of the nine reported monozygotic female twin pairs concordant for sex chromosomal aneuploidy.*

Furthermore, in our opinion, the reported data for the three remaining twin pairs (Decourt et al, 1964 ; Klempman, 1964; Riekhof, 1972) are not sufficient for accurate assessment of mosaicism. Thus, we are unaware of any monozygotic twin pair definitely concordant for non-mosaic 45,X. At least in part, this finding can be explained by severe selection in utero against 45, $\mathrm{X}$ fetuses, especially in twin pregnancies.

The association between monozygotic twinning and chromosomal mosaicism may not be unique to gonadal dysgenesis. Although mosaicism has not been reported frequently in monozygotic twins with Down's or Klinefelter's syndrome, one should be cautious in interpreting results of studies in which adequate techniques for the detection of mosaicism and zygosity were not applied. In any event, the findings in our case, when added to previous reports, strengthen the probability that in gonadal dysgenesis there is real association between mosaicism and monozygotic twinning (Nance and Uchida, 1964; Benirschke and Kim, 1973a and b). It is

* The twins reported by Turner and Zanartu (1962) have been cited as non-mosaic $45, \mathrm{X}$, but the cytological findings as partially indicated in the title, 'Ovarian dysgenesis in identical twins: discrepancy between nuclear chromatin patterns in somatic cells and in blood cells', strongly suggest mosaicism. 
likely that the association is based on some fundamental relationship, but a more definitive answer requires intensive study of more cases of phenotypically normal as well as abnormal monozygotic twin pairs.

We wish to thank Dr Schuyler M. Bissell of Everett, Washington, for referring this patient to us.

\section{REFBRENCES}

Barr, M., Carr, D., Plunkett, E., Soltan, H., and Wiens, R. (1967). Male pseudohermaphroditism and pure gonadal dysgenesis in sisters. American fournal of Obstetrics and Gynecology, 99, 10471055.

Benirschke, K. and Kim, C. K. (1973a). Multiple pregnancy-part I. New England fournal of Medicine, 288, 1276-1284.

Benirschke, K. and Kim, C. K. (1973b). Multiple pregnancy-part II. New England fournal of Medicine, 288, 1329-1336.

Caspersson, T., Hultén, M., Jonasson, J., Lindsten, J., Therkelsen, A., and Zech, L. (1971). Translocations causing non-fluorescent $\mathrm{Y}$ chromosomes in human $\mathrm{XO} / \mathrm{XY}$ mosaics. Hereditas Genetisk Arkiv, 68, 317-324.

Cummins, H. and Midlo, C. (1961). Finger Prints, Palms and Soles, ch. 5. Dover Publications, New York.

Decourt, J., Lejeune, J., Michard, J.-P., and Petrover, M. (1964). Syndrome de Turner haplo-X typique chez deux jumelles monozygotes. Annales d'Endocrinologie, 25, 438-440.

Edwards, J. H., Dent, T., and Kahn, J. (1966). Monozygotic twins of different sex. Fournal of Medical Genetics, 3, 117-123.

Fathalla, M., Rasha 1, M., and Kerr, M. (1966). The relationship between ovarian tumors and intersex states with special reference to the disgerminoma and arrhenoblastoma. Fournal of Obstetrics and Gynaecology of the British Commonwealth, 73, 812-820.

Ferrier, P. E., Ferrier, S. A., and Kelley, V. C. (1970). Sex chromosome mosaicism in disorders of sexual differentiation: incidence in various tissues. Fournal of Pediatrics, 76, 739-744.

Fialkow, P. (1966). Autoimmunity and chromosomal aberrations. American fournal of Human Genetics, 18, 93-108.

Fialkow, P. and Uchida, I. (1968). Autoantibodies in Down's syndrome and gonadal dysgenesis. Annals of the New York Academy of Sciences, 155, 759-769.

Jacobs, P. A. (1969). The chromosome basis of some types of intersexuality in man. Fournal of Reproduction and Fertility, 7, Suppl. No. 2, 73-78.

Josso, N., Nezelof, C., Picon, R., de Grouchy, J., Dray, F., and Rappaport, R. (1969). Gonadoblastoma in gonadal dysgenesis : a report of two cases with 46,XY/45,X mosaicism. Fournal of Pediatrics, 74, 425-437.

Klempman, S. (1964). The investigation of developmental sexual abnormalities. South African Medical fournal, 38, 234-236.

Lemli, L. and Smith, D. W. (1963). The XO syndrome: a study of the differentiated phenotype in 25 patients. Fournal of Pediatrics, 63, 577-588.

LoCurto, F., Scappaticci, S., Zuffardi, O., Chierichetti, G., and
Fraccaro, M. (1972). Non-fluorescent $Y$ chromosome in a 45,X/ 46,XY mosaic. Annales de Génétique, 15, 107-110.

Mikkelsen, M., Froland, A., and Ellebjerg, J. (1963). XO/XX mosaicism in a pair of presumable monozygotic twins with different phenotypes. Cytogenetics, 2, 86-98.

Muller, P., Clavert, J., Rihm, G., and Gillet, J. Y. (1970). Mosaique $45, \mathrm{XO} / 46, \mathrm{XX} / 47, \mathrm{XXX}$ chex deux jumelles monozygotes: concordances et discordances cliniques et biologiques. Annales d'Endocrinologie, 31, 1143-1152.

Nance, W. E. and Uchida, I. (1964). Turner's syndrome, twinning, and an unusual variant of glucose-6-phosphate dehydrogenase. American fournal of Human Genetics, 16, 380-392.

Nicolis, G. L., Hsu, L. Y., Sabetghadam, R., Kardon, N. B., Chernay, P. R., Mathur, D. P., Rose, H. G., Hirschhorn, K., and Gabrilove, J. L. (1972). Klinefelter's syndrome in identical twins with the 46,XX chromosome constitution. American fournal of Medicine, 52, 482-491.

Nielsen, J. (1967). Inheritance in monozygotic twins. Lancet, 2, 717-718.

Potter, A. M. and Taitz, L. S. (1972). Turner's syndrome in one of monozygotic twins with mosaicism. Acta Paediatrica Scandinavica, 61, 473-476.

Rainer, J. D., Abdullah, S., and Jarvik, L. F. (1972). XYY karyotype in a pair of monozygotic twins: a 17-year life-history study. British fournal of Psychiatry, 120, 543-548.

Riekhof, P. L., Horton, W. A., Harris, D. J., and Schimke, R. N. (1972). Monozygotic twins with the Turner syndrome. American fournal of Obstetrics and Gynecology, 112, 59-61.

Ross, G. T., Tjio, J. H., and Lipsett, M. B. (1969). Cytogenetic studies of presumptively monozygotic twin girls discordant for gonadal dysgenesis. Fournal of Clinical Endocrinology and Metabolism, 29, 440-445.

Russell, A., Moschos, A., Butler, L. J., and Abraham, J. M. (1966). Gonadal dysgenesis and its unilateral variant with testis in monozygous twins: related to discordance in sex chromosomal status. Fournal of Clinical Endocrinology and Metabolism, 26, 1281-1292.

Shine, I. B. and Corney, G. (1966). Turner's syndrome in monozygotic twins. Fournal of Medical Genetics, 3, 124-128.

Starkman, M. and Jaffe, R. (1967). Chromosome aberrations in $\mathrm{XO} / \mathrm{XY}$ mosaic individuals and their fathers. American fournal of Obstetrics and Gynecology, 99, 1056-1066.

Taylor, H., Barter, R. H., and Jacobson, C. (1966). Neoplasms of dysgenetic gonads. American Fournal of Obstetrics and Gynecology, 86, 816-821.

Turner, H. H, and Zanartu, J. (1962). Ovarian dysgenesis in identical twins: discrepancy between nuclear chromatin pattern in somatic cells and in blood cells. Fournal of Clinical Endocrinology and Metabolism, 22, 660-665.

Turpin, R., Lejeune, J., Lafourcade, J., Chigot, P.-L., and Salmon, C. (1961). Présomption de monozygotisme en dépit d'un dimorphisme sexuel : sujet masculin XY et sujet neutre Haplo X. Comptes Rendus Hebdomadaires des Séances de l'Académie des Sciences, 252, 2945-2946.

Van der Horst, R., Frankel, J., and Grace, J. (1971). Congenital hypertrophic pyloric stenosis in phenotypic female twins with X/XX mosaicism. Archives of Disease in Childhood, 46, 554-556.

Zellweger, H. (1968). Familial aggregates of the 21-trisomy syndrome. Annals of the New York Academy of Sciences, 155, 784792. 